\title{
POLITICAL ANALYSIS
}

www.pan.oxfordjournals.org

Volume 23 Number 2 Spring 2015

Editors' Note

R. Michael Alvarez and Jonathan N. Katz

Articles

How Robust Standard Errors Expose Methodological Problems They Do Not Fix, and What to Do About It

Gary King and Margaret E. Roberts

Using the Predicted Responses from List Experiments as Explanatory Variables in Regression Models

Kosuke Imai, Bethany Park, and Kenneth F. Greene

Dynamic Estimation of Latent Opinion Using a Hierarchical Group-Level IRT Model Devin Caughey and Christopher Warshaw

What's in a Name? A Method for Extracting Information about Ethnicity from Names J. Andrew Harris

Estimating Voter Registration Deadline Effects with Web Search Data

Alex Street, Thomas A. Murray, John Blitzer, and Rajan S. Patel

A Cross-National Measure of Electoral Competitiveness

Mark Andreas Kayser and René Lindstädt

Computer-Assisted Text Analysis for Comparative Politics

Christopher Lucas, Richard A. Nielsen, Margaret E. Roberts, Brandon M. Stewart, Alex Storer, and Dustin Tingley

A Continuous-Time, Latent-Variable Model of Time Series Data

Alexander M. Tahk

Letters

Estimating the Severity of the WikiLeaks U.S. Diplomatic Cables Disclosure Michael Gill and Arthur Spirling

Underreporting in Political Science Survey Experiments: Comparing Questionnaires to Published Results

Annie Franco, Neil Malhotra, and Gabor Simonovits 


\section{Political Analysis}

\section{Editors-in-Chief:}

Jonathan N. Katz (California Institute of Technology, USA)

R. Michael Alvarez (California Institute of Technology, USA)

Associate Editors:

Janet Box-Steffensmeier (Ohio State University, USA)

Patrick Brandt (University of Texas, Dallas, USA)

Kosuke Imai (Princeton University, USA)

Simon Jackman (Stanford University, USA)

Jasjeet Sekhon (University of California, Berkeley, USA)

Betsy Sinclair (Washington University at St. Louis, USA)

\section{Advisory Board:}

Neal Beck (New York University, USA)

Andrew Gelman (Columbia University, USA)

Vera Troeger (University of Warwick, UK)

\section{Editorial Board}

Fred Boehmke (University of Iowa, USA)

Jake Bowers (University of Illinois at Urbana-Champaign, USA)

Henry Brady (University of California, Berkeley, USA)

John Brehm (University of Chicago, USA)

Elisabeth Gerber (University of Michigan, Ann Arbor, USA)

Jeff Gill (Washington University, St. Louis, USA)

Kristian Gleditsch (University of Essex, UK)

Donald Green (Columbia University, USA)

Justin Grimmer (Stanford University, USA)

Jens Hainmueller (Stanford University, USA)

Michael Herron (Dartmouth College, USA)

Simon Hix (London School of Economics, UK)

Simon Hug (Université de Genève,

Switzerland)

William Jacoby (Michigan State University, USA)

Brad Jones (University of California, Davis, USA)

Orit Kedar (Hebrew University of Jerusalem)

Gary King (Harvard University, USA)

Thomas Koenig (University of Mannheim, Germany)

Jeffrey Lewis (University of California, Los Angeles, USA)
Suzanna Linn (Pennsylvania State University, USA)

John Londregan (Princeton University, USA)

Samantha Luks (YouGovPolimetrix, USA)

Cherie Maestas (Florida State University, USA)

Andrew Martin (Washington University, St. Louis, USA)

Walter Mebane (University of Michigan, Ann Arbor, USA)

Adam Meirowitz (Princeton University, USA)

Sara Mitchell (University of Iowa, USA)

Jonathan Nagler (New York University, USA)

Thomas Palfrey (California Institute of Technology, USA)

John Patty (Washington University, St. Louis, USA)

Thomas Plümper (University of Essex, UK)

Kevin Quinn (University of California, Berkeley, USA)

Philip Schrodt (Pennsylvania State University, USA)

Arthur Spirling (Harvard University, USA)

James Stimson (University of North Carolina, Chapel Hill, USA)

Langche Zeng (University of California, San Diego, USA) 
Political Analysis (ISSN 1047-1987) is published quarterly in January, April, July, and October as the official journal of the Society for Political Methodology and the Political Methodology Section of the American Political Science Association. The journal is published by Oxford University Press. Postmaster: send address changes to Political Analysis, Journals Customer Service Department, Oxford University Press, 2001 Evans Road, Cary, NC 27513, USA.

Instructions for Authors

Authors interested in submitting to Political Analysis should consult the instructions to authors available on the Political Analysis Web site (www.pan.oxfordjournals.org).

Subscriptions

A subscription to Political Analysis comprises 4 issues. Prices include postage; for subscribers outside the Americas, issues are sent air freight. Annual Subscription Rate (Volume 23, 4 issues, 2015)

Institutional

Print edition and site-wide online access: US\$566/£378/€566

Print edition only: US\$521/£347/€521

Site-wide online access only: US\$453/£302/€453

Personal

Print edition only: US\$105/£71/€105

Please note: UK£ rate applies to UK and Rest of World, except US and Canada (\$) and Europe (€).

There may be other subscription rates available; for a complete listing, please visit

http://www.oxfordjournals.org/our_journals/polana/access_purchase/price_list.html.

Full pre-payment in the correct currency is required for all orders. Payment should be in US dollars for orders being delivered to the USA or Canada; Euros for orders being delivered within Europe (excluding the UK); GBP sterling for orders being delivered elsewhere (i.e., not being delivered to USA, Canada, or Europe). All orders should be accompanied by full payment and sent to your nearest Oxford Journals office. Subscriptions are accepted for complete volumes only. Orders are regarded as firm, and payments are not refundable. Our prices include Standard Air as postage outside of the UK. Claims must be notified within four months of despatch/order date (whichever is later). Orders from the UK will be subject to a VAT charge. For orders from elsewhere in the EU you or your institution should account for VAT by way of a reverse charge. Please provide us with your or your institution's VAT number. If registered, please supply details to avoid unnecessary charges. For subscriptions that include online versions, a proportion of the subscription price may be subject to UKVAT. Subscribers in Canada, please add GST to the prices quoted. Personal rate subscriptions are only available if payment is made by personal cheque or credit card, delivery is to a private address, and is for personal use only.

The current year and two previous years' issues are available online at www.periodicals.com/oxford.html or from Oxford University Press Previous volumes from the Periodicals Service Company, 11 Main Street, Germantown, NY 12526, USA. E-mail: psc@periodicals.com. Tel: (518) 537-4700. Fax: (518) 537-5899.

Contact information: Journals Customer Service Department, Oxford University Press, Great Clarendon Street, Oxford OX2 6DP, UK. E-mail:jnls.cust.serv@oup.com. Tel: +44 (0)1865 353907. Fax: +44 (0)1865 353485. In the Americas, please contact: Journals Customer Service Department, Oxford University Press, 2001 Evans Road, Cary, NC 27513, USA. E-mail: jnlorders@oup.com. Tel: (800) 852-7323 (toll-free in USA/Canada) or (919) 677-0977. Fax: (919) 677-1714. In Japan, please contact: Journals Customer Service Department, Oxford University Press, 4-5-10-8F Shiba, Minato-ku, Tokyo, 108-8386, Japan. E-mail: custserv.jp@oup.com. Tel: (81) 3 5444 5858. Fax: (81) 3 3454 2929.

Methods of payment: (i) Check (payable to Oxford University Press, to Oxford University Press, Cashiers Office, Great Clarendon Street, Oxford OX26DP, UK) in GB£ Sterling (drawn on a UK bank), US\$ Dollars (drawn on a US bank), or EU€ Euros. (ii) Bank transfer to Barclays Bank Plc, Oxford Group Office, Oxford (bank sort code 20-65-18) (UK), overseas only Swift code BARC GB 22 (GB£ Sterling to account no. 70299332, IBAN GB89BARC20651870299332; US\$ Dollars to account no. 66014600, IBAN GB27BARC20651866014600; EU€ Euros to account no. 78923655, IBAN GB16BARC20651878923655). (iii) Credit card (Mastercard, Visa, Switch or American Express).

Oxford Journals Environmental and Ethical Policies

Oxford Journals, a division of Oxford University Press, is committed to working with the global community to bring the highest quality research to the widest possible audience. Oxford Journals will protect the environment by implementing environmentally friendly policies and practices wherever possible. Please see http://www.oxfordjournals.org/ethicalpolicies.html for further information on environmental and ethical policies.

Digital object identifiers

For information on dois and to resolve them, please visit www.doi.org.

Permissions

For information on how to request permissions to reproduce articles or information from this journal, please visit www.oxfordjournals.org/jnls permissions.

\section{Indexing and abstracting}

The journal is included in the Social Science Citation Index, Current Contents/Social \& Behavioral Sciences, and Statistical Theory \& Method Abstracts.

\section{Advertising}

Inquiries about advertising should be sent to Advertising and Special Sales, Oxford Journals, Oxford University Press, Great Clarendon Street, Oxford, OX2 6DP, UK. Tel: +44 (0)1865 354767; Fax: +44 (0)1865 353774; E-mail: jnlsadvertising@oup.com.

\section{Disclaimer}

Statements of fact and opinion in the articles in Political Analysis are those of the respective authors and contributors and not of the Society for Political Methodology or Oxford University Press. Neither Oxford University Press nor the Society for Political Methodology make any representation, express or implied, in respect of the accuracy of the material in this journal and cannot accept any legal responsibility or liability for any errors or omissions that may be made. The reader should make her or his own evaluation as to the appropriateness or otherwise of any experimental technique described.

(C)2015 The Society for Political Methodology

All rights reserved; no part of this publication may be reproduced, stored in a retrieval system, or transmitted in any form or by any means, electronic, mechanical, photocopying, recording, or otherwise without prior written permission of the publisher or a license permitting restricted copying issued in the UK by the Copyright Licensing Agency Ltd, 90 Tottenham Court Road, London W1P 9HE, or in the USA by the Copyright Clearance Center, 222 Rosewood Drive, Danvers, MA 01923. 


\title{
Political Analysis
}

\author{
www.pan.oxfordjournals.org
}

\section{Volume $23 \quad$ Number 2 \\ Spring 2015}

\section{Contents}

Editors' Note

157

R. Michael Alvarez and Jonathan N. Katz

\section{Articles}

How Robust Standard Errors Expose Methodological Problems They Do Not Fix, and What to Do About It

Gary King and Margaret E. Roberts

Using the Predicted Responses from List Experiments as Explanatory Variables in Regression Models

Kosuke Imai, Bethany Park, and Kenneth F. Greene

Dynamic Estimation of Latent Opinion Using a Hierarchical Group-Level IRT Model

Devin Caughey and Christopher Warshaw

What's in a Name? A Method for Extracting Information about Ethnicity from Names

J. Andrew Harris Alex Street, Thomas A. Murray, John Blitzer, and Rajan S. Patel

A Cross-National Measure of Electoral Competitiveness Mark Andreas Kayser and René Lindstädt

Computer-Assisted Text Analysis for Comparative Politics Christopher Lucas, Richard A. Nielsen, Margaret E. Roberts, Brandon M. Stewart, Alex Storer, and Dustin Tingley

A Continuous-Time, Latent-Variable Model of Time Series Data Alexander M. Tahk

\section{Letters}

Estimating the Severity of the WikiLeaks U.S. Diplomatic Cables Disclosure Michael Gill and Arthur Spirling

Underreporting in Political Science Survey Experiments: Comparing Questionnaires to Published Results Annie Franco, Neil Malhotra, and Gabor Simonovits 